\title{
PASAR DAN PEMASARAN
}

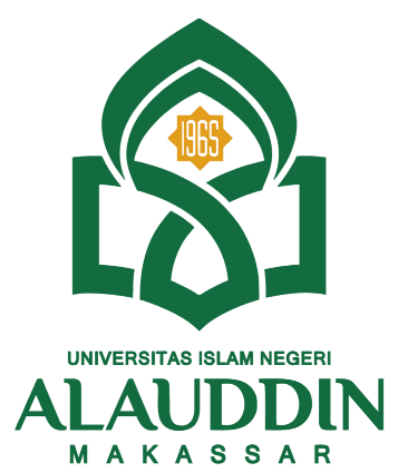

Makalah Ini Disusun untuk Memenuhi Tugas Pada Mata Kuliah Kewirausahaan Dosen Pengampu:

Dra. Hj. Nuraeni Gani, M.M. NIP: 196412111991032001

Disusun Oleh:

Miftahul Jannah

NIM: 90500120098

PROGRAM STUDI PERBANKAN SYARIAH

FAKULTAS EKONOMI DAN BISNIS ISLAM

UNIVERSITAS ISLAM NEGERI ALAUDDIN MAKASSAR 


\section{KATA PENGANTAR}

Puji syukur penulis panjatkan kepada Allah swt karena berkat karunia-Nya sehingga penulis dapat menyelesaikan makalah ini yang berjudul Pasar dan Pemasaran dengan tepat waktu. Makalah ini ditulis dengan tujuan untuk menambah pengetahuan bagi penulis pada khususnya dan bagi para pembaca pada umumnya. Selain itu ditujukan untuk memenuhi tugas pada mata kuliah Kewirausahaan.

Penulis mengucapkan terima kasih kepada Ibu Dra. Hj. Nuraeni Gani, M.M. selaku dosen pada mata kuliah kewirausahaan yang telah memberikan tugas ini serta membimbing dalam penulisan makalah ini.

Penulis menyadari bahwa dalam penulisan makalah ini masih terdapat banyak sekali kekurangan. Oleh karena itu, penulis mengarapkan kritik dan saran yang membangun demi kesempurnaan makalah ini.

Gowa, 27 November 2021

Penulis 


\section{DAFTAR ISI}

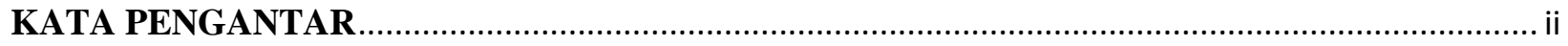

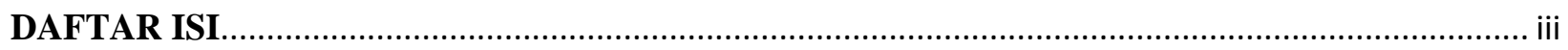

BAB I

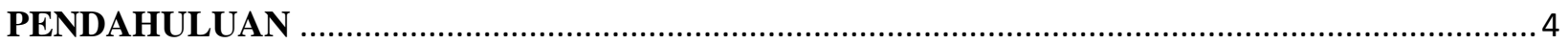

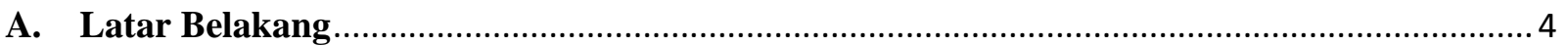

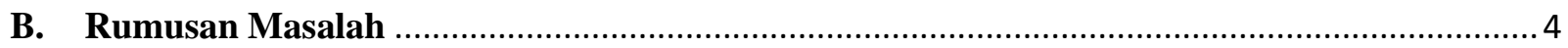

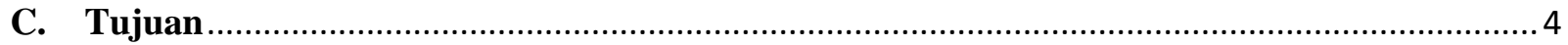

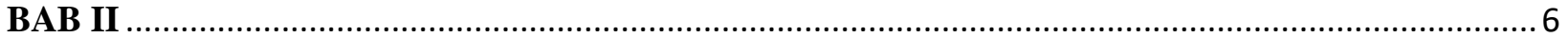

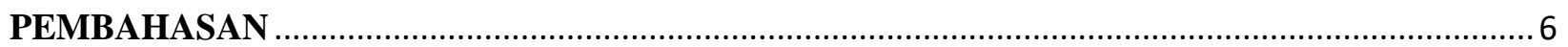

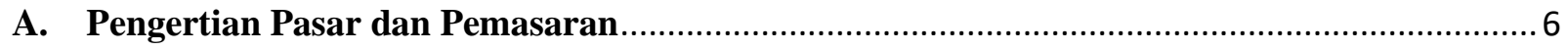

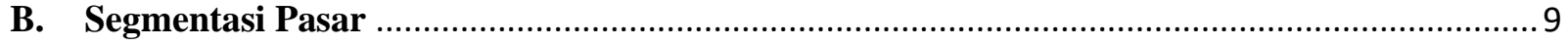

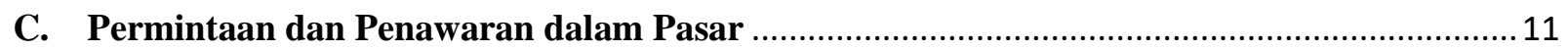

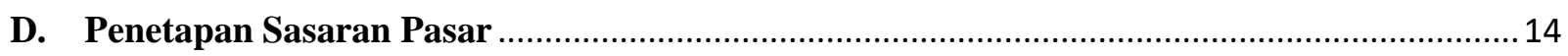

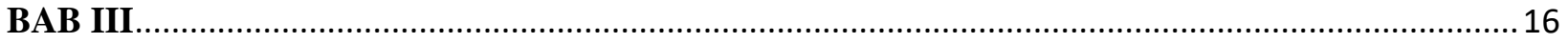

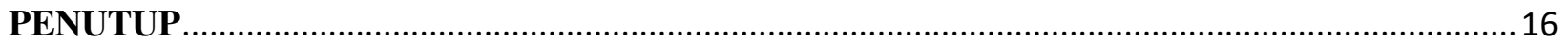

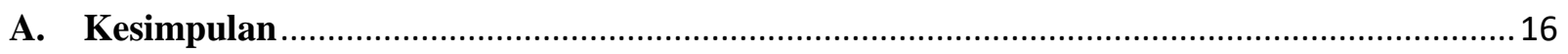

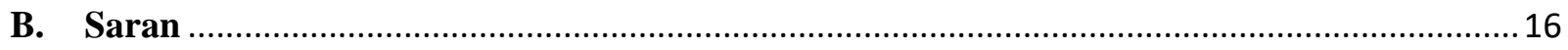

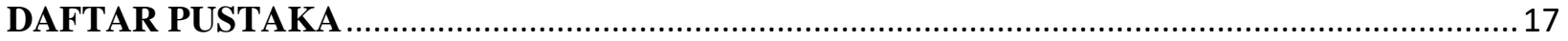




\section{BAB I}

\section{PENDAHULUAN}

\section{A. Latar Belakang}

Pada dasarnya tujuan dalam mendirikan perusahaan adalah mencari laba yang semaksimal mungkin. Keberhasilan suatu perusahaan dalam mencapai tujuan itu sangat dipengaruhi oleh kemampuan perusahaan dalam memasarkan produknya, yaitu bila perusahaan dapat menjual produknya dengan harga yang menguntungkan pada tingkat kualitas yang diharapkan, serta mampu mengatasi tantangan dari para pesaing terutama dalam bidang pemasaran. Oleh karena itu, menarik konsumen melakukan pembelian, maka perusahaan harus bisa menerapkan suatu strategi pemasaran yang tepat sesuai dengan kondisi pasar yang dihadapi.

Keberhasilan strategi pemasaran dipengaruhi oleh beberapa faktor yaitu riset dan analisis pasar,keputusan tentang produk, penetapan harga, promosi, dan distribusi. Agar produk yang dipasarkan dapat berhasil, maka perusahaan harus menggunakan konsep pemasaran yang meliputi manfaat, mutu atau kualitas dan kepuasan antara kebutuhan dengan keinginan. Oleh karena itu perusahaan harus bisa mempengaruhi konsumen untuk dapat menciptakan permintaan atas produknya. Sedangkan alatyang digunakan perusahaan untuk, memperkenalkan produk dan mendorong masyarakat melakukan pembelian adalah promosi.

\section{B. Rumusan Masalah}

Berdasarkan latar belakang yang telah diuraikan diatas, maka rumusan masalah dalam penulisan makalah ini yaitu:

1. Apa pengertian pasar dan pemasaran?

2. Bagaimana cara melakukan penelitian pasar?

3. Bagaimana segmentasi pasar?

4. Bagaiamana permintaan dan penawaran yang terjadi dalam pasar?

\section{Tujuan}

Dari rumusan masalah tersebut, maka tujuan penulisan makalah ini yaitu:

1. Untuk mengetahuai pengertian pasar dan pemasaran 
2. Untuk mengetahu dan memahami bagaimana cara melakukan penelitian pasar

3. Untuk mengetahui dan memahami bagaimana bagaimana segmentasi pasar

4. Untuk mengetahui dan memahami bagaiamana permintaan dan penawaran yang terjadi dalam pasar 


\section{BAB II}

\section{PEMBAHASAN}

\section{A. Pengertian Pasar dan Pemasaran}

\section{Pengertian Pasar}

Seorang yang membeli suatu barang atau jasa akan terlibat dalam suatu transaksi pembelian. Transaksi jual beli yang terjadi dilakukan oleh penjual dan pembeli. Kejadian ini berlangsung pada saat tertentu di tempat tertentu. Sehingga pasar dapat dianggap sebagai suatu tempat. Pengertian pasar sebagai tempat ini sebenarnya sangat sempit dan kurang fleksibel. Oleh karena itu defenisi pasar yang lebih luas (Stanton): Pasar adalah orang-orang yang mempunyai keinginan untuk puas, uang untuk berbelanja, dan kemauan untuk membelanjakannya. Dari defenisi tersebut dapatlah diketahui adanya tiga unsur penting yang terdapat dalam pasar, yaitu:
a. Orang dengan segala keinginannya
b. Daya beli mereka
c. Kemauan untuk membelanjakan uangnya

Secara konkret pasar adalah tempat bertemunya pembeli dan penjual untuk melakukan transaksi jual beli barang atau jasa. Namun seiring dengan kemajuan zaman dan teknologi yang menyebabkan transaksi dapat dilakukan tanpa mempertemukan penjual dan pembeli secara langsung, maka muncul pengertian pasar dalam arti luas, yaitu proses interaksi penjual dan pembeli untuk mencapai harga pasar.

Ada beberapa pendapat menurut ahli berbeda antara satu dengan yang lain, berikut pendapat para ahli :

a. Menurut Kotler dan Amstrong 1999, mendefinisikan pasar adalah pembeli yang mempunyai kemampuan aktual dari sebuah benda atau jasa yang penjual akan menawarkan produk atau jasa sebagai gantinya penjual mendapatkan informasi dan uang.

b. Menurut Atep Adya Barata Pasar merupakan tempat bertemunya pembeli dan penjual. Menurut Atep, pertemuannya ini tak harus dilakukan secara langsung. Bisa jadi melalui media tertentu atau perantara, lalu sesudah pertemuan, pertukaran pun terjadi. 
c. Menurut William J. Stanton pasar adalah tempat dimana para penjual dapat mempromosikan,mengenalkan, serta mendistribusikan barang atau jasa. Dimana disana juga ada kumpulan dari sekian banyak warga yang memiliki tujuan untuk mendapatkan rasa puas. Rasa puas itu berasal dari penggunaan uang untuk ditukar dengan barang atau jasa yang mereka inginkan.

d. Menurut Simamora pasar adalah suatu kelompok atau perkumpulan masyarakat untuk membeli barang tertentu dengan keinginan dan kebutuhannya. Tak hanya itu, mereka juga mempunyai kemampuan menjual dan membeli barang tersebut. Dan kesempatan tukarmenukar barang dengan alat pembayaran ada di dalam pasar.

e. Menurut Handri Ma'aruf pasar merupakan ruang untuk para penjual dan pembeli bertransaksi. Di dalam pasar, ada penawaran dan permintaan antara si pembeli dan si penjual dan terjadilah transaksi jual beli.

Pada pokoknya, pasar dapat dikelompokkan ke dalam empat golongan, yaitu:

a. Konsumen adalah sekelompok pembeli yang membeli barang untuk dikonsumsikan, bukannya dijual atau diproses lebih lanjut. Termasuk dalam pasar konsumen ini adalah pembeli-pembeli individual dan / atau pembeli rumah tangga (non bisnis). Barang yang dibeli adalah barang konsumsi.

b. Pasar industri adalah pasar yang terdiri atas individu-individu dan lembaga atau organisasi yang membeli barang-barang untuk dipakai lagi, baik secara langsung maupun secara tidak langsung, dalam memproduksi barang lain yang kemudian dijual. Barang yang dibeli adalah barang industri.

c. Pasar Penjual adalah suatu pasar yang terdiri atas individu-individu dan organisasi yang membeli barang-barang dengan maksud untuk dijual lagi atau disewakan agar mendapatkan laba.

d. Pasar pemerintah adalah pasar dimana terdapat lembaga-lembaga pemerintah seperti departemen-departemen, direktorat, kantorkantor dinas dan instansi lain.

\section{Pengertian Pemasaran}

Pemasaran adalah aliran produk secara fisik dan ekonomi dari produsen melalui pedagang perantara ke konsumen. Definisi lain menyatakan bahwa pemasaran adalah suatu proses sosial dan manajerial yang membuat individu/kelompok mendapatkan apa yang mereka butuhkan dan 
inginkan dengan menciptakan, menawarkan dan mempertukarkan produk yang bernilai kepada pihak lain. Pemasaran melibatkan banyak kegiatan yang berbeda yang menambah nilai produk pada saat produk bergerak melalui sistem tersebut.

Ada beberapa definisi mengenai pemasaran diantaranya adalah sebagai berikut

a. Philip Kotler (Marketing) pemasaran adalah kegiatan manusia yang diarahkanuntuk memenuhi kebutuhan dan keinginan melalui proses pertukaran.

b. Menurut Philip Kotler dan Amstrong pemasaran adalah sebagai suatu prosessosial dan managerial yang membuat individu dan kelompok memperoleh apayang mereka butuhkan dan inginkan lewat penciptaan dan pertukaran timbal balik produk dan nilai dengan orang lain.

c. Pemasaran adalah suatu sistem total dari kegiatan bisnis yang dirancang untukmerencanakan, menentukan harga, promosi dan mendistribusikan barang- barang yang dapat memuaskan keinginan dan mencapai pasar sasaran serta tujuan perusahaan.

d. Menurut W Stanton pemasaran adalah sistem keseluruhan dari kegiatan usahayang ditujukan untuk merencanakan, menentukan harga, mempromosikan danmendistribusikan barang dan jasa yang dapat memuaskan kebutuhan pembeli maupun pembeli potensial.

Kegiatan-kegiatan dalam usaha pemasaran tidak hanya kegiatan memindahkan barang /jasa dari tangan produsen ke tangan konsumen saja dengan sistem penjualan, tetapi banyak kegiatan lain yang juga dijalankan dalam kegiatan pemasaran. Penjualan hanyalah salah satu dari berbagai fungsi pemasaran. Apabila pemasar melakukan pekerjaan dengan baik untuk mengidentifikasi kebutuhan konsumen, mengembangkan produk dan menetapkan harga yang tepat, mendistribusikan dan mempromosikannya secara efektif, maka akan sangat mudah menjual barang-barang tersebut.

Konsep-konsep inti pemasaran meluputi: kebutuhan, keinginan, permintaan, produksi, utilitas, nilai dan kepuasan; pertukaran, transaksi dan hubungan pasar, pemasaran dan pasar. Kita dapat membedakan antara kebutuhan, keinginan dan permintaan. Kebutuhan adalah suatu keadaan dirasakannya ketiadaan kepuasan dasar tertentu. Keinginan adalah kehendak yang kuat akan pemuas yang spesifik terhadap kebutuhan-kebutuhan yang lebih mendalam. Sedangkan 
Permintaan adalah keinginan akan produk yang spesifik yang didukung dengan kemampuan dan kesediaan untuk membelinya.

\section{B. Segmentasi Pasar}

\section{Pengertian Segmentasi Pasar}

Segmentasi pasar adalah sebuah strategi yang dilakukan oleh perusahaan untuk membagi kelompok konsumen ke beberapa kategori seperti kebutuhan, karakteristik maupun perilaku yang berbeda di dalam suatu pasar tertentu. Pelaksanaan segmentasi pasar membutuhkan beberapa proses dan tahapan yang turut serta wajib dilakukan menggunakan aporisma supaya mencapai sasaran yang diinginkan.

Sederhananya, segmentasi pasar juga bisa didefinisikan menjadi proses identifikasi serta analisis pembeli terhadap produk dan keterkaitan antara disparitas ciri konsumen yang ada di pasar.

2. Tujuan Segmentasi Pasar

Tujuan segmentasi pasar dapat dijabarkan seperti berikut:

a. Meningkatkan pelayanan konsumen supaya lebih baik

Setiap pembeli atau konsumen niscaya akan memperhatikan empat hal yang krusial ketika memenuhi kebutuhannya yaitu harga, kualitas, pelayanan, dan ketepatan waktu.

b. Membuat strategi pemasaran dapat lebih terarah

Dengan adanya market segmentation taktik pemasaran pasar homogen mampu lebih terarah, termasuk waktu menyusun harga, produk, distribusi, dan promosi. Selain itu, memakai adanya segmentasi pasar pengelompokkan pasar sebuah perusahaan bisa lebih terarah termasuk dalam mengarahkan dana dan usahanya ke pasar yang lebih menguntungkan.

c. Dapat digunakan buat merencanakan bisnis dan mengevaluasi target

Dengan adanya segmentasi pasar, sebuah perusahaan mampu melakukan evaluasi terhadap semua aktivitas pemasaran sebelumnya. Hal itu tentunya bisa membantu perusahaan supaya 
mampu mengetahui taktik pemasaran yang sinkron menggunakan ciri pasar supaya mampu sebagai acuan waktu akan menciptakan perencanaan usaha kedepannya.

d. Dapat mengenal lawan perusahaan

Sesudah perusahaan tahu pembeli yang terdapat dalam segmen pasar, selanjutnya perusahaan jua mampu mengenal siapa saja yang termasuk kompetitor pada sebuah segmen yang sama. Selain itu, aktivitas kompetitor jua mampu diketahui sang perusahaan. Dengan demikian, maka perusahaan mampu mencontoh \& memeriksa taktik pemasaran yang dilakukan sang competitor tadi supaya mampu merogoh perhatian konsumen.

3. Variabel utama dalam segmentasi pasar industrial

Pada umumnya dapat dikatakan bahwa perusahaan akan lebih berhasil apabila membagibagi konsumennya kedalam beberapa segmen. Cara ini lebih menjamin keberhasilan daripada melayani konsumen dengan apa adanya. Salah satu caranya dengan melakukan pendekatan yang penting dalam segmentasi pasar, seperti membagi pasar kedalam beberapa jenis pasar yang ada.

Seperti yang dikemukakan oleh Assauri (2012), Ia membagi segmentasi menjadi empat variabel segmentasi utama bagi konsumen. Variabel segmentasi yang umum digunakan adalah variabel geografis, demografis, psikografis, dan perilaku.

\section{a. Segmentasi geografis}

Segmentasi geografis digunakan untuk mengklasifikasikan pasar berdasarkan lokasi yang akan mempengaruhi biaya operasional dan jumlah permintaan secara berbeda. Dalam segmentasi geografi, pasar dibagi menjadi unit geografis, seperti: negara, provinsi, kota atau lingkungan. Segmentasi pasar ini dilakukan dengan mengelompokkan konsumen menjadi bagian pasar menurut skala wilayah atau letak geografis yang dapat dibedakan berdasarkan:

- Wilayah

Dapat diperoleh segmen pasar yang berupa pasar lokal, pasar regional, pasar nasional, dan pasar luar negeri atau ekspor. Masing-masing pasar berdasarkan wilayah ini berbeda-beda dan cara menanganinya.

- Iklim 
Dengan dasar ini, diperoleh segmen pasar yang berupa pasar daerah pegunungan dan dataran tinggi serta pasar daerah pantai dan dataran rendah. Masing-masing pasar berdasarkan iklim ini berbeda kebutuhan, keinginan, dan preferensinya.

- Kota atau desa

Dapat diperoleh segmen pasar yang berupa pasar daerah perkotaan dan pasar daerah desa atau pertanian. Masing-masing segmen pasar ini berbeda potensi serta motif, perilaku, dan kebiasaan pembeliannya sehingga membutuhkan cara penanganan pemasaran berbeda.

b. Segmentasi demografis

Dalam segmentasi demografis, pasar dibagi menjadi kelompok-kelompok berdasarkan variabel-variabel demografis seperti usia, ukuran keluarga, siklus kehidupan keluarga, jenis kelamin, penghasilan, pekerjaan, agama, ras, generasi kewarganegaraan, dan kelas sosial. Variabel-variabel demografis adalah dasar yang paling populer untuk membedakan kelompokkelompok pelanggan.

c. Segmentasi psikografis

Segmentasi psikografis, segmen pasar ini dilakukan dengan mengelompokkan konsumen atau pembeli menjadi bagian pasar menurut variabel-variabel pola atau gaya hidup (life style) dan kepribadian (personality). Sebagai contoh, segmen pasar masyarakat yang bergaya hidup konsumtif dan mewah berbeda dengan segmen pasar masyarakat yang bergaya hidup produktif dan hemat yang mementingkan kualitas dengan harga yang relatif murah.

d. Segmentasi perilaku

Dalam segmentai perilaku pasar diklasifikasi dalam kelompok-kelompok yang dibedakan berdasarkan pengetahuan, sikap, penggunaan atau respon terhadap suatu produk.

\section{Permintaan dan Penawaran dalam Pasar}

Permintaan dalam dunia ekonomi sering disebut dengan istilah demand yang berarti suatu keinginan konsumen untuk membeli suatu barang pada berbagai tingkat harga selama periode waktu tertentu. Atau dapat disimpulkan bahwa permintaan itu adalah banyaknya jumlah barang yang ada dalam suatu pasar tertentu, dengan tingkatan harga, tingkatan pendapatan, serta dalam periode tertentu. 
Dalam proses permintaan terdapat faktor-faktor yang mempengaruhi permintaan itu sendiri. Adapun faktor-faktor yang mempengaruhi permintaan yaitu:

1. Harga barang itu sendiri, maksudnya jika harga suatu barang semakin murah, maka permintaan terhadap barang itu bertambah dan begitu pula sebaliknya.

2. Harga barang lain yang terkait, maksudnya keterkaitan dua macam barang dapat bersifat substitusi (pengganti) dan bersifat komplementer (tambahan). Misalnya, barang substitusi dari daging sapi adalah daging ayam, ikan, atau tempe.

3. Tingkatan pendapatan per kapita, maksudnya tingkatan pendapatan per kapita disini dicermikan dengan daya beli. Makin tingginya tingkat pendapatan daya beli makin kuat sehingga permintaan terhadap suatu barang meningkat.

4. Selera atau kebiasaan, maksudnya walaupun harga barang itu sama, tetapi minat terhadap barang itu kurang.

5. Jumlah penduduk, maksudya jumlah penduduk memiliki peranan penting pada kegiatan permintaan, dikarenakan semakin banyak penduduk semakin pula banyak permintaan.

6. Perkiraan harga dimasa mendatang, maksudnya apabila kita memperkirakan harga suatu barang itu akan naik, maka lebih baik membeli barang itu sekarang, sehingga mendorong orang untuk membeli lebih banyak barang lagi, guna menghemat dimasa yang akan datang.

7. Distribusi pendapatan, maksudnya jika distribusi pendapatan buruk, berarti daya beli akan melemah, sehingga permintaan terhadap barang juga akan menurun.

8. Usaha-usaha produsen meningkatkan penjualan, maksudnya usaha-usaha yang dilakukan agar permintaan pada suatu barang itu meningkat dengan cara, promosi atau pengiklanan.

Permintaan sendiri memiliki macam-macam bentuk dalam kegiatan ekonomi, dan dapat dibedakan menjadi beberapa kelompok, antara lain permintaan berdasarkan daya beli dan jumlah subyek pendukung.

1. Permintaan menurut daya beli

Menurut daya belinya permintaan dibagi menjadi tiga macam, yaitu:

a. Permintaan efektif adalah permintaan masyarakat terhadap suatu barang atau jasa yang disertai dengan daya beli atau kemampuan untuk membayar. 
b. Permintaan potensial adalah permintaan masyarakat terhadap suatu barang dan jasa yang sebenarnya memiliki kemampuan untuk membeli, akan tetapi belum melakukan pembelian barang atau jasa tersebut.

c. Permintaan absolut adalah permintaan konsumen terhadap suatu barang atau jasa yang tidak disertai dengan daya beli. Maksudnya konsumen tidak mempunyai kemampuan (uang) untuk membeli barang yang diinginkan.

2. Permintaan menurut jumlah subyek pendukung

Berdasarkan jumlah subyek pendukung, permintaan itu sendiri terdiri atas permintaan:

a. Permintaan individu adalah permintaan yang dilakukan oleh seseorang untuk memenuhi kebutuhan hidupnya sendiri.

b. Permintaan kolektif (permintaan pasar) adalah kumpulan dari permintaan-permintaan perorangan/individu atau permintaan secara keseluruhan para konsumen dipasar.

Penawaran dalam dunia ilmu ekonomi sering disebut (supply) yang berarti jumlah barang yang produsen ingin tawarkan (jual) pada berbagai tingkatan harga selama satu periode tertentu. Atau dapat disimpulkan, penawaran adalah banyaknya barang yang ditawarkan oleh penjual, pada suatu pasar tertentu, periode tertentu, serta pada tingkatan harga tertentu. Jika dicermati sebenarnya pengertian permintaan dan penawaran itu hanya berbeda pada satu kata. Jika permintaan menggunakan kata membeli, maka penawaran menggunakan kata menjual. Seperti juga dalam permintaan, penawaran juga sama menganalisis serta mengasumsikan suatu periode waktu tertentu, dan faktor-faktor penentu penawaran selain harga barang dianggap tidak berubah (ceteris paribus).

Tidak berbeda dengan permintaan, dalam ekonomi islam penawaran memiliki definisi bahwa jumlah barang atau jasa yang ditawarkan harus transparan dan terperinci spesifikasinya, bagaimana keadaan barang tersebut, apa kelebihan dan kekurangan dari barang tersebut, jangan sampai penawaran yang kita lakukan dapat merugikan pihak lain dalam arti ini pihak yang mengajukan permintaan akan barang dan jasa tersebut. Seperti halnya permintaan definisi penawaran dalam ilmu ekonomi konvensional maupun ilmu ekonomi islam relatif sama. Hanya saja ada prinsip-prinsip tertentu ada yang harus diperhatikan oleh individu khususnya individu muslim dalam keinginannya dalam menjalankan kegiatan ekonomi. 
Dalam penawaran, ada pula beberapa faktor yang mempengaruhi dalam hal menentukan penawaran diantaranya:

1. Biaya dan teknologi

Biaya dan teknologi adalah dua konsep yang sangat erat berkaitan satu sama lain. Adapun yang dimaksud dengan biaya adalah sesuatu yang dikeluarkan untuk memproduksi barang dan jasa, yang mencakup biaya ketenaga kerjaan, biaya bahan baku, biaya sewa mesin, biaya administrasi, serta biaya bunga atas pinjaman modal. Sedangkan teknologi adalah penemuan dan peningkatan yang diterapkan untuk menurunkan biaya produksi.

2. Jumlah Penjual

Jumlah penjual sudah sangat jelas memiliki dampak bagi penawaran. Dikarenakan makin banyak jumlah penjual yang mampu menjual pada tigkat harga tertentu, maka akan berimbas pada tingginya penawaran itu sendiri.

\section{Dugaan tentang masa depan}

Faktor ini mencakup dugaan mengenai perubahan harga barang dari barang tersebut dikemudian hari.

\section{Kodisi alam}

Kondisi alam sangat mempengaruhi proses penawaran, dikarenakan apabila kondisi alam tidak menentu seperti halnya terjadi banjir, tanah longsor, gunung meletus, bisa mempengaruhi penawaran terhadap barang-barang berkurang.

\section{Penetapan Sasaran Pasar}

Kotler dan Armstrong (1997: 242) menyatakan penetapan pasar sasaran adalah melakukan evaluasisetiap segmen pasar dan memutuskan yang mana dan berapa banyak yang akan dilayani. Hermawan Kartajaya dkk. (2003: 50) mendefinisikan penetapan pasar sasaran sebagai strategi untuk mengalokasikan sumber daya perusahaan secara efektif dimana sumber daya selalu berada dalam jumlah terbatas. Penetapan sasaran (setting objectives) adalah langkah penting dalam proses perencanaan. Suatuperusahaan yang telah menetapkan sasarannya mengetahui apa yang ingin dia capai dengan strategiyang ditetapkannya, dan kapan suatu strategi dikatakan telah berjalan dengan 
baik. Tanpa sasaran, langkah strategi dan segala sesuatu yang mengikutinya tidak ada artinya sama sekali.

Sebagian besar ahli sepakat bahwa pendekatan logis untuk melakukan tugas sulit menetapkan sasaranpemasaran adalah dengan bergerak dari yang umum menuju yang khusus. Pasar sasaran (Target Market) adalah sekelompok konsumen atau pelanggan yang secara khususmenjadi sasaran usaha pemasaran bagi sebuah perusahaan.

\section{Strategi Untuk Menyeleksi Sasaran Pasar}

Ada tiga strategi umum dalam menyeleksi pasar sasaran yaitu:

a. Strategi penetapan sasaran yang sama (undifferentiated targeting strategy). Yang dimaksud dengan strategi penetapan sasaran yang sama adalah pendekatan pemasaran yang memandang sebuah pasar sebagai satu pasar yang besar dengan tanpa segmen-segmen individual dan oleh karenanya memerlukan satu barang pemasaran saja.

b. Strategi sasaran terkonsentrasi (concentrated targeting). Dengan strategi penetapan sasaran terkonsentrasi ini sebuah perusahaan akan menyeleksi satu ceruk pasar (market niche-satu segmen dari suatu pasar) untuk menargetkan upaya-upaya pemasarannya. Karena perusahaan menarik satu segmen saja, maka dapat berkonsentrasi untukmemahami kebutuhan, motivasi dan kepuasan dari anggota segmen dan mengembangkan serta mempertahankan bauran pemasaran yang sangat khusus.

c. Strategi penetapan sasaran segmen majemuk (multisegment targeting strategy). Yang dimaksud strategi penetapan sasaran segmen majemuk adalah sebuahstrategi yang memilih dua atau lebih segmen pasar yang didefinisikan dengan baik dan mengembangkan bauran pemasaran yang berbeda untuk setiap segmen pasar tersebut. 


\section{BAB III}

\section{PENUTUP}

\section{A. Kesimpulan}

1. Pasar adalah tempat bertemunya pembeli dan penjual untuk melakukan transaksi jual beli barang atau jasa. Namun seiring dengan kemajuan zaman dan teknologi yang menyebabkan transaksi dapat dilakukan tanpa mempertemukan penjual dan pembeli secara langsung, maka muncul pengertian pasar dalam arti luas, yaitu proses interaksi penjual dan pembeli untuk mencapai harga pasar. Sedangkan pemasaran adalah suatu proses sosial dan manajerial yang membuat individu/kelompok mendapatkan apa yang mereka butuhkan dan inginkan dengan menciptakan, menawarkan dan mempertukarkan produk yang bernilai kepada pihak lain.

2. Segmentasi pasar adalah sebuah strategi yang dilakukan oleh perusahaan untuk membagi kelompok konsumen ke beberapa kategori seperti kebutuhan, karakteristik maupun perilaku yang berbeda di dalam suatu pasar tertentu.

3. Permintaan adalah banyaknya jumlah barang yang ada dalam suatu pasar tertentu, dengan tingkatan harga, tingkatan pendapatan, serta dalam periode tertentu. Sedangkan penawaran adalah banyaknya barang yang ditawarkan oleh penjual, pada suatu pasar tertentu, periode tertentu, serta pada tingkatan harga tertentu.

4. Penetapan pasar sasaran sebagai strategi untuk mengalokasikan sumber daya perusahaan secara efektif dimana sumber daya selalu berada dalam jumlah terbatas.

\section{B. Saran}

Penulis menyarankan agar pembaca dapat memahami lebih jauh tentang pasar dan pemasaran. Selain itu penulis juga berharap kritik dan saran yang membangun. 


\section{DAFTAR PUSTAKA}

Arif, Nurul Ainun. 2014. Pasar dan Pemasaran. Accessed September 27, 2021. https://www.academia.edu/9951668/Pasar_dan_Pemasaran.

Hariansyah, Novan. 2021. "Segmentasi Pasar Dalam Komunikasi Pemasaran Islam." Jurnal AlHikmah 19 (2): 127-138.

Jordan, Akhmad Dwi. 2020. "MEKANISME HUBUNGAN PERMINTAAN DALAM MEMPENGARUHI PASAR." Jurnal Ekonomi Umsida 1 (2): 1-18.

Kasdi, Abdurrohman. 2016. "Permintaan dan Penawaran dalam Mempengaruhi Pasar." Jurnal Bisnis dan Manajemen Islam 4 (2): 18-34.

Muawanah. 2017. "PERMINTAAN DAN PENAWARAN DALAM ISLAM." Jurnal Syari'ah dan Hukum Islam 2 (2): 111-127.

2021. Pintek.id. Accessed September 27, 2021. https://pintek.id/blog/segmentasi-pasar/.

Rahmi, Ain. 2015. "Mekanisme Pasar Dalam Islam." Jurnal Ekonomi Bisnis dan Kewirausahaan 4 (2): 177-192.

https://id.scribd.com/embeds/433236151/content?start_page=1\&view_mode=scroll\&access_key $=k e y-f F e x x f 7 r l b z E f W u 3 H K w f$ 